\title{
Erodibility of Vertisols in relation to agricultural practices along a toposequence in the Logone floodplain
}

\author{
Simon Djakba Basga ${ }^{1 *}$, Jean Pierre Temga ${ }^{2}$, Désiré Tsozué ${ }^{3}$, Arafat Gove ${ }^{1}$, Bourou Sali and Jean Pierre Nguetnkam ${ }^{4}$ \\ ${ }^{1}$ Institute of Agricultural Research for Development (IRAD), P.O. Box 415 Garoua, Cameroon \\ ${ }^{2}$ Department of Earth Sciences, Faculty of Science, University of Yaoundé 1. \\ P.O Box 812 Yaoundé, Cameroon \\ ${ }^{3}$ Department of Earth Sciences, Faculty of Science, University of Maroua. P.O Box 814 Maroua, Cameroon \\ ${ }^{4}$ Department of Earth Sciences, Faculty of Science, University of Ngaoundéré, \\ P.O Box 454 Ngaoundéré, Cameroon \\ [Received: May 27, 2019 Accepted: August 06, 2019 Published Online: December 13, 2019]
}

\begin{abstract}
Knowledge of the combining effect of agricultural practices and slope on soil erodibility is important to promote their suitable use and constitutes a key parameter for their sustainable conservation. The aim of this study was to characterize vertisols from the Logone floodplain and evaluate their erodibility in relation to the agricultural practices and slope in order to suggest the well managing strategies to be diffused. Vertisols were characterized by describing their profile type and their erodibility was assessed by sampling topsoils at 3 positions along a toposequence (upslope, midslope and footslope). Erodibility indexes were computed by exploiting physicochemical data. The studied vertisols were classified as gleyic Vertisols. They are clayey (19$42 \%$ of clay), slightly basic ( $p H \sim 7.3$ ) and display high organic matter (OM) content and cation exchange capacity. Smectites and kaolinite were the main clay minerals associated with quartz. The water dispersible clay, clay dispersion ratio and dispersion ratio diminished from the upslope to the footslope, while clay aggregation showed an opposite trend. Hence, vertisols from the upslope and midslope cropped were more erodible than those from the not cropped footslope. From the statistical analysis, it appeared that $\mathrm{Na}^{+}$, $\mathrm{Ca}^{++}$ and $\mathrm{K}^{+}$contributed to vertisols erodibility while $\mathrm{Mg}^{++}$, OM and amorphous Fe promoted aggregate stability. Managing these vertisols will tend to limit $N$ and $K$ rich inputs (urea and NPK fertilizers); control liming strategies and encourage substantial OM inputs. No-tillage or minimum tillage oriented perpendicularly to the slope are the practices to be implemented.
\end{abstract}

Keywords: Vertisols, erodibility, land use, logone floodplain, slope

\section{Introduction}

Soil erodibility in tropical area is the susceptibility of soil particles to be disrupted and transported, generally by water and wind. This is sometimes related to soil properties, landscape features, land use and depends on the strength of forces holding the particles and the intensity of disruptive forces (Wuddivira and Camps-Roach 2007; Igwe et al., 2009; Essien, 2013). Thus, soils poor in binding agents are generally susceptible to erosion even at low rainfall energies and runoff (Igwe et al., 2009). An ability of the microaggregates to be disrupted or their stability can be used to estimate and to predict soil erosion (Rhoton et al., 2007; Igwe et al., 2009; Nguetnkam and Dultz, 2011; Essien, 2013; Basga et al., 2018). Most studies always used dispersion indexes such as water dispersible clay (WDC), dispersion ratio (DR), and aggregates stability indexes like clay flocculation index (CFI), clay aggregation (CA) and aggregation of silt and clay (ASC) (Igwe et al., 2009; Nguetnkam and Dultz, 2014). Other indexes associated to soil properties as exchangeable sodium percentage (ESP) were also used (Nguetnkam and Dultz, 2011).

The actions of aggregating or dispersing agents on soil erodibility are important in defining management strategies to be adopted in soil conservation. These actions vary with soil type (Igwe et al., 1995; Basga et al., 2018). Role of organic matter as aggregating agent has been described (Tisdall and Oades, 1982; Six et al., 2004; Tejada and Gonzalez, 2006). Fe and Al oxides, calcium and magnesium also play an important role in aggregate

\footnotetext{
*Email: simonbajak@yahoo.fr
} 
stability (Duiker et al., 2003; Igwe et al., 2009) while sodium is recognized as dispersive agent (Igwe, 2005; Nguetnkam and Dultz, 2011; Basga et al., 2018). Igwe et al. (2009) noted that in floodplain soils from western Nigeria, the total oxalate and dithionite Mn oxides as well as $\mathrm{Fe}$ and $\mathrm{Al}$ oxides including soil organic matter were the best aggregating agents. It was reported in the study made by Nguetnkam and Dultz (2011) that no correlations existed between sesquioxides and aggregates stability in oxisols. Another important factor to be well considered in soil erodibility is slope characteristics and agricultural practices (Roose, 1994; Lal, 1997; Tahernezami, 2013; Jamshidi and Afrous, 2015; Basga et al., 2018).

Soil erosion which is one of the most serious environmental problems in cultivated areas is of a global concern. In northern Cameroon, soils were recognized as highly erodible when used in agriculture (Azinwi et al., 2011; Nguetnkam and Dultz, 2014; Basga et al., 2018). This erodibility can depend on soil properties, relief, farming practices and management strategies. Demographic pressure in the far north Cameroon has led to farming vertisols in the Logone floodplain which were considered as marginal soils and not cultivated in the past. These fragile ecosystems rich in clay deposits (Olivry, 1986) had become large areas for agriculture exposing them to erosion. Here, erosion proceeds by dispersing and transporting particles during rains and flood periods. This was exacerbated by agricultural practices responsible for soil cover destruction, organic matter decline and rapid runoff.

In northern Cameroon, numerous pedological studies carried out were focused mainly on pedogenesis factors (Brabant, 1968; Gavaud et al., 1976) and soil resources cartography (Humbel and Barbery, 1973; Brabant and Gavaud, 1985). Soil degradation and soil fertility restoration were also approached (Seini-Boukar et al., 1991; Nguetnkam and Dultz, 2011; 2014; Basga and Nguetnkam, 2015). The most studies on erodibility had concerned alfisols, ultisols and oxisols (Roose and Barthes, 2001; Nguetnkam and Dultz, 2011, 2014; Fils et al., 2014; Basga et al., 2018). Few studies were oriented to vertisols features and the combined impact of agricultural practices and slope on their erodibility in floodplain conditions. Based on these studies, the present study was planned to (1) characterize vertisols from the Logone floodplain, (2) assess their erodibility and (3) determine the influence of agricultural practices and slope on vertisols erodibility.

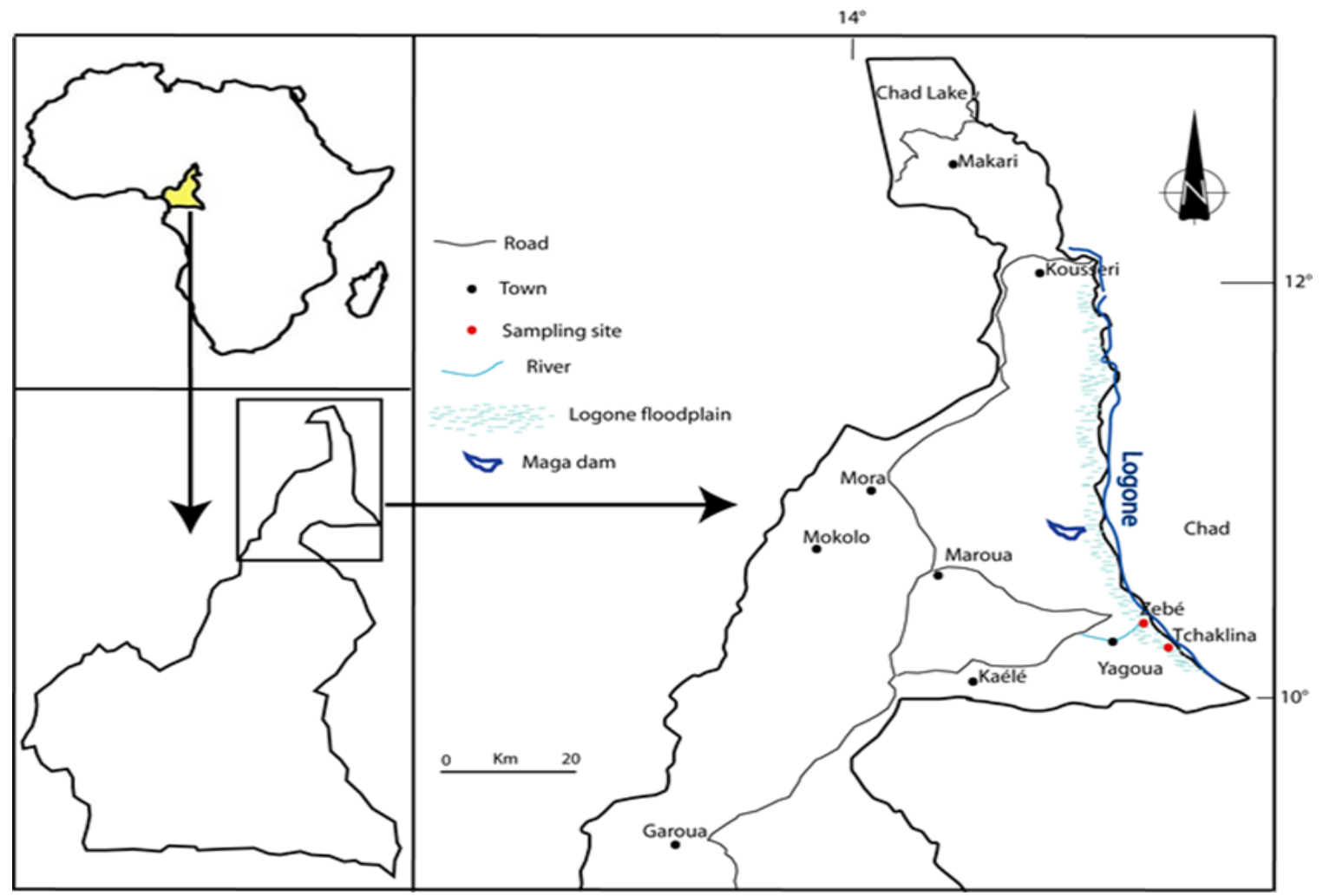

Figure 1: Location of the studied area 


\section{Materials and Methods}

\section{Study area and Sampling procedure}

The study area is the Logone floodplain located at about $8 \mathrm{~km}$ near Yagoua town in the Far North region of Cameroon (Figure 1). The climate is characterized by a high inter and intra annual variability. Annual rainfall varies between 800 and $850 \mathrm{~mm}$, and occurs from May to October (L'Hote, 2000). The rainiest months are August and September, period during which the study area is submerged by flood. The pattern of flooding and the depth of the flood vary from year to year. Usually, a large area of the plain is flooded to a depth of $1 \mathrm{~m}$ with maximum of $3 \mathrm{~m}$. The mean monthly temperature varies between 16 and $39^{\circ} \mathrm{C}$. The natural vegetation is a dry savannah dominated by flooded prairies associated to Faidherbia albida, Zizifus mauritiana and Acacia sieberiana (Letouzey, 1985). Geological formations are Quaternary sedimentary formations represented by clays, silts and sand deposits (Pias, 1970). Vertisols are the dominant soil groups in the floodplain (Temga et al., 2019).

Vertisols morphological organizations were obtained through two pits opened at Zebe $\left(10^{\circ} 18^{\prime} 64^{\prime \prime} \mathrm{N} ; 1^{\circ} 18^{\prime} \mathrm{E}\right)$ and Tchaklina $\left(10^{\circ} 16^{\prime} \mathrm{N} ; 1^{\circ} 17^{\prime} \mathrm{E}\right)$ (Figure 1) and described in detail according to the standard procedure (FAO, 2006). Logone floodplain vertisols presented the same morphological organizations in the 2 opened pits. Thus, just one profile was described in this paper. Soil sampling for erodibility study was made on a toposequence (about $300 \mathrm{~m}$ long) at Tchaklina. The upslope (US) of this toposequence, $329 \mathrm{~m}$ above sea level (A.S.L), is frequently tilled and submitted to rainy sorghum cultivation; the midslope (MS) located at $326 \mathrm{~m}$ A.S.L, which is regularly submitted to sorghum in rainy season was replaced by tobacco in dry season while the footslope (FS) is located at $324 \mathrm{~m}$ A.S.L and is subjected to grazing during the dry season. Vertisols were sampled at the different plots of the cultural horizon $(0-20 \mathrm{~cm})$. At each part of the sequence, a composite soil sample was obtained by mixing and quartering all samples collected. Samples were air-dried and passed through a $2 \mathrm{~mm}$ sieve before laboratory analyses.

\section{Laboratory processes}

Laboratory analyses consisted of the particle size distribution, $\mathrm{pH}$, available phosphorus $(\mathrm{P})$, exchangeable bases, cations exchange capacity (CEC), total nitrogen (TN), organic carbon and amorphous $\mathrm{Al}$ and Fe. These analyses were carried out at the Soils, Plants, Fertilizers and Environment Laboratory Analysis of the Faculty of
Agronomy and Agricultural Sciences, University of Dschang (Cameroon).

The pipette method was used for particle size distribution analysis after dispersion with sodium hexametaphosphate (WRB, 2014). Water dispersible clay and silt (WDC, WDS) were determined by the same procedure except that a chemical dispersant was not used. Soil $\mathrm{pH}$ Water $\left(\mathrm{H}_{2} \mathrm{O}\right)$ was measured with $\mathrm{pH}$ meter equipped with a glass electrode in 1:2.5 soil-water suspensions (Jackson, 1973). Soil organic carbon (OC) was measured by Walkley-Black procedure (Walkley and Black, 1934). The content in organic matter was calculated by multiplying the $\mathrm{OC}$ values with the factor 1.724 (Walkley and Black, 1934) in cropped soil and by factor 2 in fallow soil. The total nitrogen (TN) was measured by the Kjeldahl procedure. Available phosphorus was determined by Bray II method. Exchangeable cations were extracted by ammonium acetate at $\mathrm{pH} 7$ and CEC was determined by the sodium saturation method. The Electrical conductivity (EC) was measured according to Nguetnkam and Dultz (2014). Soil amorphous elements $\left(\mathrm{Fe}_{\mathrm{ox}}\right.$ and $\mathrm{Al}_{\mathrm{ox}}$ ) were extracted using ammonium oxalate and were determined by following the method outlined by Schwertmann (1964).

Mineralogical composition was determined on oriented clay samples by X-ray diffraction (XRD) coupled to Fourier transform infrared spectroscopy (FTIR) at the Institute of soil sciences from Leibniz University at Hannover. The clay fraction $(<2 \mu \mathrm{m})$ was separated first by dispersing in deionized water and sedimentation according to Stoke's law. The resulting clay suspension was freeze-dried. The XRD data were obtained by using a PHILIPS diffractometer with $\mathrm{CuK} \alpha$ radiation. The relative amount of each mineral was estimated via the intensity of the principal basal reflexion. The FTIR spectroscopy is a commonly used method to investigate the structure, bonding and chemical properties of clay (Madejová, 2003). The FTIR spectra were recorded using Fourier transform spectrometer Bruker IFS 55 with a resolution of $4 \mathrm{~cm}^{-1}$ in the $400-4000 \mathrm{~cm}^{-1}$ range as described by Petit et al. (1998). The spectra were acquired on a mixture containing $70 \mathrm{mg}$ of clay and $370 \mathrm{mg}$ of $\mathrm{KBr}$ and obtained by accumulating 200 scans.

Chemical analyses were carried out using emission spectrometry. For each sample, $200 \mathrm{mg}$ of soil powder $(<$ $250 \mu \mathrm{m})$ was molded in fused lithium borate $\left(\mathrm{LiBO}_{2}\right)$ and dissolved in nitric acid $\left(\mathrm{HNO}_{3}\right)$. Inductive Coupled Plasma by Atomic Emission Spectrometry (ICP-AES) was used for the determination of major elements and Inductive Coupled Plasma by Mass Spectrometry (ICP-MS) was used for trace elements. 


\section{Data analyses}

Particle size distribution results were used to determine dispersion of the soil particles through erodibility indexes as outlined by Nguetnkam et al. (2011). These indexes were calculated as follow:

- $\quad$ Clay dispersion ratio $(\mathrm{CDR}): \mathrm{CDR}=\mathrm{WDC}\left(\mathrm{g} \mathrm{kg}^{-1}\right)$ /TC $\left(\mathrm{g} \mathrm{kg}^{-1}\right)$, where TC is total clay;

- Dispersion ratio (DR): $\mathrm{DR}=\left[\mathrm{WDC}\left(\mathrm{g} \mathrm{kg}^{-1}\right)+\right.$ WDS $\left.\left(\mathrm{g} \mathrm{kg}^{-1}\right)\right] /\left[\mathrm{TC}\left(\mathrm{g} \mathrm{kg}^{-1}\right)+\mathrm{TS}\left(\mathrm{g} \mathrm{kg}^{-1}\right)\right]$ with TS as total silt and WDS as water dispersible silt;

- $\quad$ Clay aggregation $(\mathrm{CA}): \mathrm{CA}=\mathrm{TC}\left(\mathrm{g} \mathrm{kg}^{-1}\right)-\mathrm{WDC}$ $\left(\mathrm{g} \mathrm{kg}^{-1}\right)$.

The erodibility indexes (WDC, CDR, DR and CA) and physicochemical data were subjected to Pearson's correlation using XLSTAT 2007 computer package in order to determine their possible relationships.
60-130 cm: $\mathrm{B}_{21}$ tg horizon, gray (2.5Y 5/1), angular blocky, clayey, few yellowish-brown spots, compact, slickensides; strongly plastic;

130- $155 \mathrm{~cm}: \mathrm{B}_{22}$ tg horizon, yellowish brown $(2.5 \mathrm{Y}$ 6/3), angular blocky, clayey; brownish spots (10YR 6/4), strongly plastic, diffuse boundary with the underlying horizon;

155- $170 \mathrm{~cm}: \mathrm{B}_{3}$ tg horizon, brown (10YR 6/3), some red spots, angular blocky, clayey, firm, plastic.

Particle size distribution revealed that except the surface horizon, all vertisol horizons were clayey. The clay fraction increases from the top to the bottom of the profile (19 to $45 \%$ ). The $\mathrm{pH}$ which fluctuated between 7.1 and 7.4 is slightly alkaline. The CEC and exchangeable bases are globally moderate and represented essentially by $\mathrm{Ca}^{++}$and $\mathrm{Mg}^{++}$. Organic carbon is also moderate and relatively higher in the top horizons as well as total nitrogen (Table 1).

Table 1. Physical and chemical properties of Logone floodplain vertisols

\begin{tabular}{|c|c|c|c|c|c|c|c|c|c|c|c|c|c|c|}
\hline \multirow{2}{*}{$\begin{array}{l}\text { Horizon } \\
\text { depth (cm) }\end{array}$} & \multicolumn{3}{|c|}{ Particle size distribution (\%) } & \multicolumn{2}{|c|}{ Organic matter $(\%)$} & \multirow{2}{*}{$\frac{\mathrm{mg} \mathrm{kg}^{-1}}{\mathrm{P}}$} & \multicolumn{6}{|c|}{ Cations exchange capacity $\left(\mathrm{cmol} \mathrm{kg}^{-1}\right)$} & \multicolumn{2}{|c|}{ pH } \\
\hline & Clay & Silts & Sand & OM & TN & & $\mathrm{Ca}^{++}$ & $\mathbf{M g}^{++}$ & $\mathbf{K}^{+}$ & $\mathrm{Na}^{+}$ & $\mathrm{S}$ & CEC & $\mathrm{H}_{2} \mathrm{O}$ & $\mathrm{KCl}$ \\
\hline$A_{g}(0-25)$ & 19 & 23 & 58 & 4.68 & 1.16 & 8.54 & 3.26 & 0.68 & 0.23 & 0.049 & 4.23 & 20.00 & 7.1 & 4.0 \\
\hline$B_{\operatorname{ltg}}(25-60)$ & 37 & 27 & 36 & 4.14 & 1.16 & 2.72 & 5.11 & 0.65 & 0.28 & 0.051 & 6.10 & 30.40 & 7.4 & 4.7 \\
\hline $\mathrm{B}_{21 \operatorname{tg}}(60-130)$ & 40 & 32 & 28 & 4.03 & 0.70 & 3.46 & 2.16 & 0.75 & 0.30 & 0.059 & 3.28 & 24.48 & 7.3 & 5.8 \\
\hline$B_{22 \operatorname{tg}}(130-155)$ & 42 & 26 & 32 & 3.15 & 0.49 & 3.27 & 5.14 & 0.77 & 0.35 & 0.062 & 6.33 & 20.48 & 7.2 & 6.0 \\
\hline$B_{3 \operatorname{tg}}(155-170)$ & 45 & 17 & 38 & 3.10 & 0.89 & 14.75 & 9.11 & 0.62 & 0.39 & 0.053 & 10.19 & 24.00 & 7.1 & 5.5 \\
\hline
\end{tabular}

\section{Results and Discussion}

\section{Morphological and Physicochemical properties of vertisols}

The studied vertisols were developed on alluvial materials (clay rich sediments). These were thin, poorly drained and exhibit desiccation cracks at surface in the dry season. The gilgai micro-reliefs were widely observed in the floodplain. Vertisol profile showed 5 horizons and from top to bottom, following organizations were observed:

0-25 cm: Ag horizon, yellowish brown (2.5Y 6/3) with hydromorphic patches (7.5YR 6/8); angular blocky, clayey, very hard; porous; presence of desiccation cracks; several fine roots; gradual and irregular boundary with the underlying horizon;

25-60 cm: $B_{1}$ tg horizon, brownish gray (2.5Y 6/2) with few yellowish-brown spots (10YR 5/6), sub angular blocky, clayey, hard, slightly porous, plastic; gradual boundary with the underlying horizon;
The clayey texture observed which is common to vertisols in condition to the highly contrasted climate were responsible of desiccations cracks at morphological level (Kovda and Wilding, 2004; Azinwi et al., 2011; Temga et al., 2019).

The high $\mathrm{pH}$ can be related to the low landscape positions with poor drainage condition promoting the bisiallitisation process (Azinwi et al., 2011; Temga et al., 2015). This result explains the moderate level of exchangeable bases which probably were partially leached.

Globally, the studied floodplain vertisols have a thin profile which is typical to less developed soils because of regular deposit of new sediments. Hydromorphic patches observed in the profile were in relation with the fact that the water table level was near the soil surface and the strongly contrasted climate with marked dry season (Vizier, 2010; Temga et al., 2019). The overall macro morphological features and physico-chemical properties enable classifying these soils as Gleyic Vertisols according to the world reference base for soil resources (WRB, 2014). 


\section{Mineralogy and Geochemistry of the studied vertisols}

The clay fraction $(<2 \mu \mathrm{m})$ of the different vertisol horizons were made up of smectites which are identified by their broad basal spacing located at $15.04 \AA$ (Figure 2) associated to kaolinite (identified by $7.2 \AA$ and $3.57 \AA$ broad

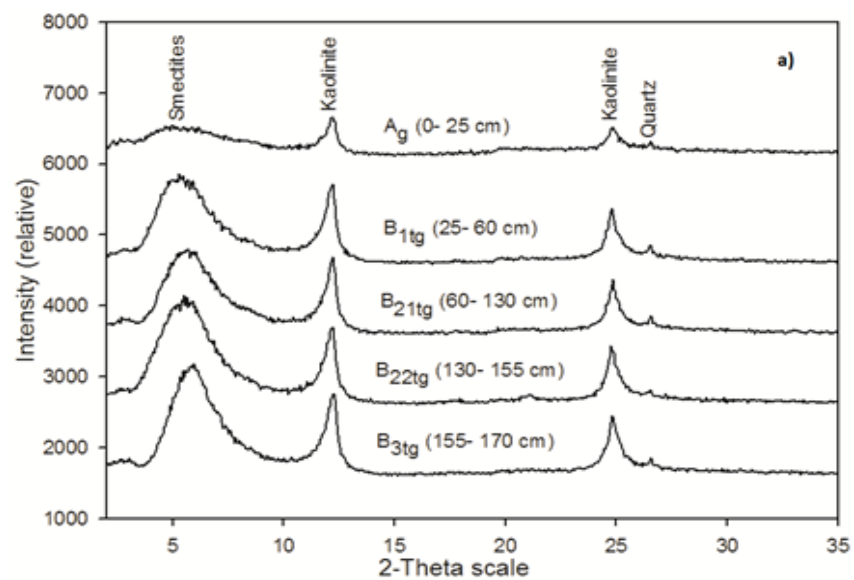

basal spacing) and quartz as observed on XRD and IR patterns (Figure 2). The coexistence of smectites and kaolinite (Table 2) was common to vertisols (Azinwi et al., 2011). The condition of poor drainage resulted from the low landscapes, the presence of clay rich parent material and the strongly contrasted climate which were favorable to bisiallitisation process leading to smectites formation (Temga et al., 2015).

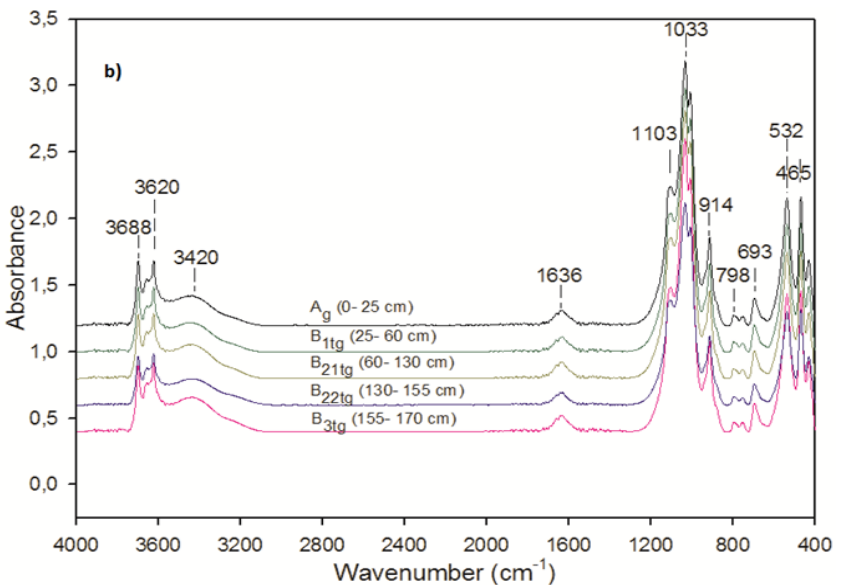

Figure 2: XRD patterns (a) and IR spectra (b) of the clay fraction $(<2 \mu \mathrm{m})$ from Logone floodplain vertisols

Table 2. Mineralogy (relative abundance), major elements, selected traces elements and loss on ignition (LOI) of Logone floodplain vertisols

\begin{tabular}{|c|c|c|c|c|c|}
\hline Horizon depth & $\begin{array}{l}A_{g} \\
(0-25 \mathrm{~cm})\end{array}$ & $\begin{array}{l}B_{1 \operatorname{tg}} \\
(25-60 \mathrm{~cm})\end{array}$ & $\begin{array}{l}B_{21 \mathrm{tg}} \\
(60-130 \mathrm{~cm})\end{array}$ & $\begin{array}{l}B_{22 t g} \\
(130-155 \mathrm{~cm})\end{array}$ & $\begin{array}{l}\text { B }_{3 \mathrm{tg}} \\
(155-170 \mathrm{~cm})\end{array}$ \\
\hline Smectites & ++ & ++ & ++++ & +++++ & +++++ \\
\hline Kaolinite & +++ & ++++ & +++ & ++++ & ++++ \\
\hline Quartz & ++ & +++ & ++ & ++ & ++ \\
\hline $\mathrm{SiO}_{2} \%$ & 54.12 & 58.72 & 56.67 & 56.43 & 56.33 \\
\hline $\mathrm{Al}_{2} \mathrm{O}_{3} \%$ & 20.87 & 19.05 & 19.82 & 18.61 & 17.94 \\
\hline $\mathrm{Fe}_{2} \mathrm{O}_{3} \%$ & 6.24 & 5.93 & 6.14 & 8.38 & 9.04 \\
\hline $\mathrm{MgO} \%$ & 0.53 & 0.41 & 0.54 & 0.43 & 0.39 \\
\hline $\mathrm{CaO} \%$ & 0.39 & 0.59 & 0.82 & 0.82 & 0.85 \\
\hline $\mathrm{Na}_{2} \mathrm{O} \%$ & 0.38 & 0.59 & 0.62 & 0.72 & 0.78 \\
\hline $\mathrm{K}_{2} \mathrm{O} \%$ & 1.88 & 2.36 & 2.26 & 2.40 & 2.50 \\
\hline $\mathrm{TiO}_{2} \%$ & 1.30 & 1.28 & 1.34 & 1.15 & 1.08 \\
\hline $\mathrm{P}_{2} \mathrm{O}_{5} \%$ & 0.17 & 0.06 & 0.05 & 0.08 & 0.42 \\
\hline $\mathrm{MnO} \%$ & 0.04 & 0.05 & 0.05 & 0.03 & 0.06 \\
\hline LOI & 13.8 & 10.7 & 11.4 & 10.6 & 10.3 \\
\hline Total & 99.94 & 99.96 & 99.95 & 99.97 & 99.96 \\
\hline $\mathrm{Ba} \mathrm{mg} \mathrm{kg}^{-1}$ & 864 & 1119 & 1302 & 1267 & 1378 \\
\hline $\mathrm{Ni} \mathrm{mg} \mathrm{kg}{ }^{-1}$ & 56 & 48 & 52 & 52 & 42 \\
\hline Sr mg kg-1 & 160 & 229 & 249 & 271 & 288 \\
\hline Zr mg kg-1 & 359 & 495 & 572 & 603 & 746 \\
\hline $\mathrm{Y} \mathrm{mg} \mathrm{kg}^{-1}$ & 32 & 33 & 36 & 30 & 35 \\
\hline $\mathrm{Nb} \mathrm{mg} \mathrm{kg}{ }^{-1}$ & 27 & 26 & 28 & 23 & 18 \\
\hline Sc mg kg-1 & 17 & 15 & 16 & 14 & 13 \\
\hline
\end{tabular}


The presence of smectites and contrasting climate control the shrink-swell pattern and constitute a key factor for the appearance of desiccation cracks.

Geochemical analysis revealed that vertisols from Logone floodplain were constituted essentially by silica $\left(54.12 \leq \mathrm{Si}_{2} \leq 93.80 \%\right)$ followed by $\mathrm{Al}_{2} \mathrm{O}_{3}(2.53-20.87 \%)$ and $\mathrm{Fe}_{2} \mathrm{O}_{3}$ (0.66-9.04\%). The predominance of these oxides was consistent with their mineralogy dominated by clay minerals and quartz. Trace elements represented were $\mathrm{Ba}\left(217-1503 \mathrm{mg} \mathrm{kg}^{-1}\right)$; $\mathrm{Zr}\left(334-1152 \mathrm{mg} \mathrm{kg}^{-1}\right)$ and $\mathrm{Sr}(26-$ $338 \mathrm{mg} \mathrm{kg}^{-1}$ ), their contents increase with depth (Table 2). These trace elements might probably result from weathering of different rocks in highlands and accumulated during sediment deposits because of low landscape position. The higher relative concentration of $\mathrm{Ba}$ is consistent with his low mobility which makes it persistent in soils and sediments (Abbaslou et al., 2014).

\section{Variation of vertisols characteristics along the toposequence}

Vertisols samples were sandy clay to silty clay with a regular angular blocky structure along the studied toposequence (Table 3 ). The content of sand increased from upslope to footslope while clay contents were higher in the midslope. This may be due to the fact that these particles are mainly deposed by flood which was governed by Stoke's law. Soil $\mathrm{pH}$ was slightly alkaline at the upslope, slightly acid at the midslope and acid at the footslope (Table 4).
Organic matter $(\mathrm{OM})$ and total nitrogen $(\mathrm{TN})$ along the sequence were high and relatively higher in the grazing vertisols located at the footslope. It also appeared that $\mathrm{OM}$ and TN diminished with slope altitude (Table 3). This result may be attributed to land use and slope gradient influence. Cropping soils were usually accompanied by a decline in OM contents (Roose and De Noni, 2004). The cropped vertisols were regularly tilled while grassland was observed as grazing vertisols. In addition, an accumulation of organic carbon rich sediments was generally important in lower slope near the river channel because the frequency and intensity of flooding decreases as the floodplain surface becomes elevated. Some authors have pointed out such significant negative interrelationships between slope gradient and OM content in floodplains (Park, 2002; Bechtold, 2007). The TN content was higher in the not cropped vertisols probably because they were covered by the native grassland which constantly released fresh matter to the soil.

The total exchangeable bases were globally low; higher values were observed at the upper part of the sequence and represented essentially by $\mathrm{Ca}^{++}$and $\mathrm{Mg}^{++}$. The CEC was globally high with the highest value recorded in the vertisols located at the footslope $\left(43.26 \mathrm{cmol} \mathrm{kg}^{-1}\right)$. This might be related to the high OM content previously mentioned (Table 3 ) and the presence of smectites in these vertisols. $\mathrm{Fe}_{\mathrm{ox}}$ fluctuated between 2.87 and $6.82 \mathrm{~g} \mathrm{~kg}^{-1}$ while $\mathrm{Al}_{\text {ox }}$ is globally low and too close in the different parts of the sequence.

Table 3: Some variation of vertisols macromorphological and particle size distribution along the toposequence

\begin{tabular}{|c|c|c|c|c|c|c|c|c|c|c|c|}
\hline \multirow[t]{2}{*}{ Sample } & \multirow[t]{2}{*}{ Sampling depth (cm) } & \multirow{2}{*}{$\begin{array}{l}\text { Munsell Colour } \\
\text { code }\end{array}$} & \multirow[t]{2}{*}{ Structure } & \multicolumn{2}{|c|}{ Consistency } & \multirow{2}{*}{$\begin{array}{c}\text { Rock } \\
\text { fragments }\end{array}$} & \multirow[t]{2}{*}{ Roots } & \multirow[t]{2}{*}{ Sand \% } & \multirow[t]{2}{*}{ Silt \% } & \multirow[t]{2}{*}{ Clay \% } & \multirow{2}{*}{$\begin{array}{c}\text { Textural } \\
\text { class }\end{array}$} \\
\hline & & & & Dry & Wet & & & & & & \\
\hline US & $0-20$ & $2.5 Y R 7 / 1$ & $3 \mathrm{c}, \mathrm{abk}$ & $\mathrm{h}$ & $s, p$ & $\mathrm{~V}$ & $\mathrm{c}, \mathrm{f}$ & 15 & 49 & 36 & Silt clay \\
\hline MS & $0-20$ & 7.5 YR $6 / 8$ & $3 \mathrm{~m}, \mathrm{abk}$ & $\mathrm{h}$ & $s, p$ & $\mathrm{n}$ & $\mathrm{f}, \mathrm{f}$ & 32 & 28 & 40 & Sandy clay \\
\hline LS & $0-20$ & 2.5 YR $7 / 1$ & $3 \mathrm{c}, \mathrm{abk}$ & $\mathrm{h}$ & $\mathrm{s}, \mathrm{p}$ & $\mathrm{V}$ & $\mathrm{f}$ & 41 & 37 & 21 & Sandy clay \\
\hline \multicolumn{7}{|c|}{ Structure } & \multicolumn{3}{|c|}{ Consistency } & \multicolumn{2}{|c|}{ Rock fragments } \\
\hline \multicolumn{2}{|r|}{ Size } & & Type & \multicolumn{3}{|c|}{ Grade } & Dry & Wet & & & \\
\hline \multicolumn{2}{|c|}{$\begin{array}{l}\mathrm{vf}=\text { very fine }(<5 \mathrm{~mm}) \\
\mathrm{f}=\text { fine }(5-10 \mathrm{~mm}) \\
\mathrm{m}=\text { medium }(10-20 \mathrm{~mm}) \\
\mathrm{c}=\text { coarse }(20-50 \mathrm{~mm}) \\
\mathrm{vc}=\text { very coarse }(>50 \mathrm{~mm}) \\
1=\text { weak } 2=\text { moderate } 3=\text { strong }\end{array}$} & \multicolumn{2}{|c|}{$\begin{array}{l}\mathrm{g}=\text { granular } \\
\mathrm{abk}=\text { angular blocky } \\
\text { sbk = subangular blocky } \\
\mathrm{l}=\text { lumpy } \\
\mathrm{m}=\text { massive }\end{array}$} & \multicolumn{3}{|c|}{$\begin{array}{l}\mathrm{w}=\text { weak (peds barely observable) } \\
\mathrm{m}=\text { moderate (peds } \\
\text { observable) } \\
\mathrm{s}=\text { strong (peds clearly observable) }\end{array}$} & $\begin{array}{l}l=\text { loose } \\
\mathrm{s}=\text { soft } \\
\mathrm{h}=\text { hard }\end{array}$ & $\begin{array}{l}\mathrm{s}=\text { sticky } \\
\mathrm{p}=\text { plastic }\end{array}$ & \multicolumn{3}{|c|}{\begin{tabular}{|l}
$\mathrm{n}=$ none $(0 \%)$ \\
$\mathrm{v}=$ very few $(0 \%-2 \%)$ \\
$\mathrm{c}=$ common $(5 \%-15 \%)$ \\
$\mathrm{m}=$ many $(15 \%-40 \%)$ \\
$\mathrm{a}=$ abundant $(40 \%-80 \%)$ \\
$\mathrm{d}=$ dominant $(>80 \%)$
\end{tabular}} \\
\hline
\end{tabular}

Table 4: Vertisols physicochemical properties and erodibility indexes along a toposequence

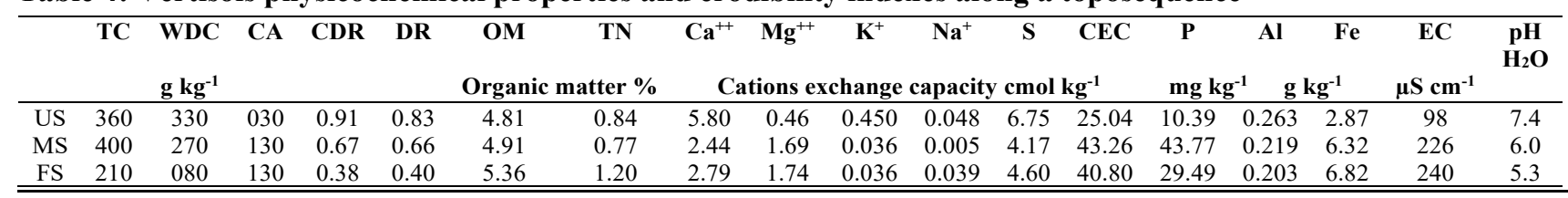

US, upslope; MS, midslope; FS, footslope; EC, electrical conductivity; OM, organic matter; P, available phosphorus; CEC, cations exchange capacity; $\mathrm{TN}$, total nitrogen 


\section{Total clay (TC), water dispersible clay (WDC), clay dispersion ratio (CDR) and vertisols erodibility}

The total clay (TC) of studied vertisols ranged from 210 to $400 \mathrm{~g} \mathrm{~kg}^{-1}$. It appeared that vertisols were most clayey at the midslope. The WDC varies with regard to land use and the position in the toposequence: the highest value was recorded in cropped vertisols located mainly at the upper and the middle slopes while the lowest one was observed in grazing vertisols located at the footslope (Table 3). The WDC indicates the ability of soil clay particles to be dispersed by water and thus, was used to estimate soil erodibility (Brubaker et al., 1992; Igwe, 2005; Igwe and Udegbunam, 2008). It was noted that higher WDC indicated a higher erodibility while low WDC indicated lower erodibility (Bajracharya et al., 1992; Igwe et al., 2009; Nguetnkam and Dultz, 2011). Thus, vertisols from the lower part of the sequence were less erodible than those from the upper and middle slopes suggesting that agricultural practices affected vertisols erodibility. Similar results were obtained in a range of soil types such as vertisols, ultisols and oxisols (Roose, 1994; Nguetnkam and Dultz, 2011; Basga et al., 2018).

The clay dispersion ratio (CDR) varied from 0.38 to 0.91 and diminished from the upper to the lower slopes (Table 3). The CDR expresses the ability of clay particles to be dispersed by water. Higher CDR showed higher susceptibility to erosion (Salako, 2001; Igwe, 2005; Nguetnkam and Dultz, 2011). Thus, cultivated vertisols were the most erodible while one located at the footslope was less erodible under grazing in agreement with the WDC results. Numerous studies pointed out an increase of soil erodibility with slope level and crop management (Martz, 1992; Lal, 1997; Mainam et al., 2002; Nguetnkam and Dultz, 2011; Gisilanbe et al., 2017). The slope gradient in this study was sufficient to have significant effect on colloidal dispersion as showed by Salako (2001). This effect appeared mostly in transport and runoff. Mainam et al. (2002) remarked on vertisols from Cameroon that cracks absorb the rainwater and runoff starts only after the closing of these cracks. Well-developed soil structure promotes a network of cracks and macro pores that accommodate infiltrating water, resulting in reduced erosion due to a decreased runoff. The conventional tillage destroys interconnected pores and rapidly increases the decomposition of plant residues (Plaza-Bonilla et al., 2010). Furthermore, hydrological properties of soils were highly influenced by agricultural practices and management (Jamshidi and Afrous, 2015). Land use influenced the soil infiltration rate by affecting soil cover and increasing WDC
(Basga et al., 2018). According to Fontes et al. (2004), runoff increased from less than $1 \%$ of rainfall under grazing cover to nearly $20 \%$ when the soil was submitted to tillage and the cover removed. Negative linear relationships between WDC and infiltration rates were established for the surface soils (Roth and Pavan, 1991). Some authors observed that soil susceptibility to erosion was influenced by slope characteristics and crop management (Martz, 1992; Roose, 1994; Lal, 1997; Jamshidi and Afrous, 2015; Gisilanbe et al., 2017; Basga et al., 2018).

\section{Dispersion ratio (DR), clay aggregation (CA) and vertisols erodibility}

The dispersion ratio (DR) which ranged between 0.40 and 0.83 decreased with slope following the same trend as CDR and WDC (Table 3). The DR expresses the ability of fine particles notably clay and silt to be dispersed by water. It was stated that higher the DR, higher will be the susceptibility of a soil to erosion (Igwe, 2005; Nguetnkam and Dultz, 2011). As observed through WDC and CDR, the DR also showed that cultivated vertisols mainly located at the upper and midslopes were the most erodible. The fact that these vertisols were regularly tilled contributes to the disorganization of their structure and consequently facilitates the mobilization of fine elements (Basga et al., 2018). The consequence of reduced aggregate stability in such soils can be important as the water infiltration rate decreases, slaking and crusting increase. One way for reducing erosion in this landscape reside on orienting tillage perpendicularly to slope. Implementation of micro-dams would be less efficient because of regular flooding with important depth.

The clay aggregation is very low at upslope $\left(30 \mathrm{~g} \mathrm{~kg}^{-1}\right)$ while in the middle and lower slopes these values are relatively high and similar. The $\mathrm{CA}$ is indicative of the ability of soil particles to be aggregated and more stable. Higher CA means higher soil stability and thus lower erodibility (Igwe et al., 2013). Thus, as indicated by WDC, CDR and DR, CA shows that the cropped vertisols located at the up part of the toposequence are more erodible and less stable than not cropped suggesting that agricultural practices and slope gradient increase their erodibility. Basga et al. (2018) obtained similar results in the irrigated and flooded vertisols from the sudano sahelian part of Cameroon.

\section{Relationships between TC, WDC, CDR, DR, $\mathrm{CA}$ and vertisols properties}

The TC is positively correlated to WDC but not significant as observed in many studies (Nguetnkam and Dultz, 2011). WDC, CDR and DR which are dispersion indexes are positively correlated between them and are all 
negatively correlated to CA. This confirms that aggregation is opposite to dispersion (Igwe et al., 2009). The fact that TC has negative correlation with CA means that the more clayey soils are not necessarily aggregated. Concerning others soil properties, the correlations with TC were also not significant (Table 5). WDC, CDR and DR are positively correlated to $\mathrm{Al}_{\mathrm{ox}}, \mathrm{Ca}^{++}, \mathrm{K}^{+}, \mathrm{Na}^{+}, \mathrm{pHH}_{2} \mathrm{O}$, total nitrogen (TN) and negatively to $\mathrm{OM}, \mathrm{Fe}_{\mathrm{ox}}, \mathrm{EC}, \mathrm{Mg}^{++}$, CEC and available P. All positive correlations were not significant while the significant negative correlation existed between OM and WDC.

OM acts generally as cementing particles agent (Oades, 1984; Brubaker et al., 1992; Chenu et al., 2000; Tejada and Gonzalez, 2006; Essien, 2013). It has capacity to bind mineral particles together developing soil structure (Tisdall and Oades, 1982; Six et al., 2000). Intense tillage degrades not only soil structure, but also contribute to a decrease of OM content which holds particles together, enabling the surface soil to resist to the detachment forces of raindrop and flood (Basga et al., 2018). In the current study, $\mathrm{OM}$ is high and considering his significant negative correlation with WDC (Table 5), it contributes significantly to reduce clay dispersion. The OM action in soil is controlled by his level, his nature and interactions with other aggregating agents (Six et al., 2000; Igwe et al., 2013; Essien, 2013). So, they may contribute to flocculation or to dispersion (Goldberg et al., 1990; Igwe et al., 1995). They can be deflocculating when they were
(Amezketa, 1999). According to Six et al. (2000), Fe and Al oxides can promote aggregation by interacting synergistically with kaolinite in low OM condition. Amorphous Al in this study was correlated positively to WDC, CDR and DR; thus, it is a dispersing agent. In contrast, $\mathrm{Fe}_{\text {ox }}$ contributes to soil aggregation because it was negatively correlated to WDC, CDR and DR and positively correlated to CA (Table 5). Duiker et al. (2003) observed also in the condition of low $\mathrm{OM}$ content that amorphous $\mathrm{Fe}$ was more effective in stabilizing soils aggregates even present in low level. According to Igwe et al. (2009), $\mathrm{Al}_{\text {ox }}$ is a dispersing agent while $\mathrm{Fe}_{\mathrm{ox}}$ is an aggregating agent in tropical soils.

Usually, $\mathrm{Ca}^{++}$is recognized for his stabilizing effect (Six et al., 2004; Wuddivira and Camps-Roach, 2007; Basga et al., 2018). The involved mechanism is the inhibition of clay dispersion and disruption of aggregates by replacement of soluble $\mathrm{Na}^{+}$which is a dispersive agent by $\mathrm{Ca}^{++}$(Wuddivira and Camps-Roach, 2007). In the presence of smectites and little amount of $\mathrm{Na}^{+}$as observed in Logone floodplain vertisols, $\mathrm{Ca}^{++}$could enhance swelling rate which may resulte in clay dispersion and disruption of aggregates. The effect of $\mathrm{Ca}^{++}$in increasing WDC after mechanical stress and aggregates breakdown of soils were widely reported (Fontes et al., 1995; Koutika et al., 1997; Wuddivira and Camps-Roach, 2007; Nguetnkam and Dultz, 2014). $\mathrm{Na}^{+}$was positively correlated to CDR and DR (Table 5) and despite his lower content in studied soils, his

Table 5: Matrix of simple linear correlations between total clay (TC), water dispersible clay (WDC), clay dispersion ratio (CDR), dispersion ratio (DR), clay aggregation (CA) and vertisols selected properties

\begin{tabular}{|c|c|c|c|c|c|c|c|c|c|c|c|c|c|c|c|c|c|}
\hline Variables & TC & WDC & CDR & DR & CA & $\mathbf{A \mathbf { l } _ { \text { ox } }}$ & $\mathrm{Fe}_{o x}$ & EC & $\mathrm{Ca}++$ & $\mathbf{M g}++$ & $\mathbf{K}+$ & $\mathrm{Na}+$ & CEC & pH $\mathrm{H}_{2} \mathrm{O}$ & $\mathbf{P}$ & TN & OM \\
\hline $\mathrm{TC}$ & 1 & & & & & & & & & & & & & & & & \\
\hline WDC & 0.908 & 1 & & & & & & & & & & & & & & & \\
\hline CDR & 0.784 & 0.972 & 1 & & & & & & & & & & & & & & \\
\hline DR & 0.823 & 0.985 & 0.998 & 1 & & & & & & & & & & & & & \\
\hline CA & -0.317 & -0.686 & -0.838 & -0.800 & 1 & & & & & & & & & & & & \\
\hline $\mathrm{Al}_{\mathrm{ox}}$ & 0.551 & 0.850 & 0.950 & 0.927 & -0.966 & 1 & & & & & & & & & & & \\
\hline $\mathrm{Fe}_{\mathrm{ox}}$ & -0.425 & -0.766 & -0.895 & -0.864 & 0.993 & -0.990 & 1 & & & & & & & & & & \\
\hline $\mathrm{EC}$ & -0.401 & -0.748 & -0.883 & -0.850 & 0.996 & -0.985 & 1.000 & 1 & & & & & & & & & \\
\hline $\mathrm{Ca}++$ & 0.227 & 0.614 & 0.783 & 0.740 & -0.996 & 0.938 & -0.978 & -0.983 & 1 & & & & & & & & \\
\hline $\mathrm{Mg}++$ & -0.353 & -0.713 & -0.858 & -0.822 & 0.999 & -0.975 & 0.997 & 0.999 & -0.991 & 1 & & & & & & & \\
\hline $\mathrm{K}+$ & 0.317 & 0.686 & 0.838 & 0.800 & -1.000 & 0.966 & -0.993 & -0.996 & 0.996 & -0.999 & 1 & & & & & & \\
\hline $\mathrm{Na}+$ & -0.487 & -0.076 & 0.161 & 0.096 & -0.674 & 0.461 & -0.584 & -0.605 & 0.740 & -0.646 & 0.674 & 1 & & & & & \\
\hline CEC & -0.197 & -0.590 & -0.763 & -0.719 & 0.992 & -0.927 & 0.971 & 0.977 & -1.000 & 0.987 & -0.992 & -0.761 & 1 & & & & \\
\hline $\mathrm{pH} \mathrm{H} \mathrm{H}_{2} \mathrm{O}$ & 0.610 & 0.886 & 0.970 & 0.952 & -0.945 & 0.997 & -0.977 & -0.970 & 0.910 & -0.957 & 0.945 & 0.395 & -0.897 & 1 & & & \\
\hline $\mathrm{P}$ & 0.118 & -0.310 & -0.525 & -0.468 & 0.905 & -0.764 & 0.849 & 0.863 & -0.941 & 0.888 & -0.904 & -0.925 & 0.951 & -0.715 & 1 & & \\
\hline $\mathrm{TN}$ & 0.945 & 0.995 & 0.944 & 0.964 & -0.610 & 0.793 & -0.698 & -0.678 & 0.533 & -0.640 & 0.610 & -0.174 & -0.507 & 0.836 & -0.214 & 1 & \\
\hline $\mathrm{OM}$ & -0.931 & -0.998 & -0.956 & -0.973 & 0.640 & -0.817 & 0.725 & 0.707 & -0.566 & 0.669 & -0.641 & 0.136 & 0.540 & -0.857 & 0.252 & -0.999 & 1 \\
\hline
\end{tabular}

made soluble generally in the situation where the ratio of fulvic to humic acid increases (Oades, 1984; Igwe, 2005).

$\mathrm{Fe}$ and $\mathrm{Al}$ sesquioxides were for a long time described to have aggregating effect (Igwe et al., 2009; 2013). The involved mechanism is soil structure improvement via organo-metallic compound formation and cationic bridging dispersive action could be severe and not to be neglected (Igwe, 2005; Nguetnkam and Dultz, 2011). The fact that amorphous Al was significantly correlated to DR implies that it is disaggregating agent which action concerns both clays and silts and then constitutes an important element to be alternatively controlled by managing strategies. 
Colloidal stability as indicated by the clay aggregation (CA) has shown that $\mathrm{CA}$ is positively correlated to $\mathrm{OM}$, $\mathrm{Fe}_{\mathrm{ox}}$, available $\mathrm{P}, \mathrm{CEC}, \mathrm{EC}$ and $\mathrm{Mg}^{++}$(Table 5); the only significant correlation is with $\mathrm{Mg}^{++}$. Thus, it is a principal element which plays an important role in aggregation in the Logone floodplain vertisols. The contribution of $\mathrm{Mg}^{++}$ in aggregates stability abounds in literature (Igwe et al., 2013) where it is well reported that $\mathrm{Mg}^{++}$is an aggregating agent in floodplain soils (Igwe et al., 2009) as well as in others soil types (Pinheiro-Dick and Schwertmann, 1996; Igwe et al., 2013). Duiker et al. (2003) also observed that $\mathrm{Fe}_{\mathrm{ox}}$ was responsible for aggregation at macroagregates level as in the current study. The contribution of OM to clay aggregation was well documented (Tisdall and Oades, 1982; Chenu et al., 2000; Six et al., 2000; Tejada and Gonzalez, 2006; Wuddivira and Camps-Roach, 2007). The positive correlation between $\mathrm{OM}$ and $\mathrm{Fe}_{\mathrm{ox}}$ (Table 5) means that both components have high relationship between them.

\section{Contribution of the study to sustainable floodplain conservation}

Floodplains were sometimes exploited to agriculture and grazing during the dry season because of their ability to supply water. In such sloping lands, intensity of agro pastoral activities are responsible for the degradation of natural resources. Soil erosion in floodplains and sloped landscapes is recognized today as an important threat to sustainable agriculture (Basic et al., 2004). In fact, erosion in flooded environments is closely responsible for soil quality degradation (responsible for crop yield decline), water quality alteration by transmitting chemical pollutants derived from inputs (fertilizers, herbicides and pesticides) in the riverbeds and vegetation destruction (Basga et al., 2018; Gonzalez et al., 2018). In floodplains, soil nutrients loss, plant available water loss and reduction of rooting depths are attributed to soil erosion with direct effect on soil productivity.

Our findings revealed that cropping practices and slope gradient increase soil susceptibility to erosion. Considering these soil erosion impacts on soil and water quality (Nguetnkam and Dultz, 2014; Basga et al., 2018; Gonzalez et al., 2018), important measures have to be taken in order to reduce these degradations. Zero tillage system or minimum tillage oriented perpendicularly to slope are practices which can limit erosion and their impacts on soil and water resources (Basic et al., 2004; Jamshidi and Afrous, 2015; Basga et al., 2018). Further, the long-term no-till system has a positive effect on runoff, soil water, OM and nitrogen contents as well as losses of ammonium-N and nitrate-N (Jamshidi and Afrous, 2015;
Gonzalez et al., 2018). Implementation of dams like earth bunds and micro catchments are also measures susceptible to limit runoff intensity and their subsequent degradation level. The obtained data revealed that $\mathrm{OM}$ content has significantly negative correlation with WDC and $\mathrm{Mg}^{++}$has significantly positive correlation with $\mathrm{CA}$ implies that the both elements contribute highly to limit soil erodibility. So, substantial OM inputs through manures and compost in the conservation practices is indispensable to soil erosion spot check including soils and water health.

\section{Conclusion}

Gleyic vertisols from Logone floodplain which are thin and poorly drained showed different degree of susceptibility to erosion along the studied toposequence with respect to land use and slope gradient. Our findings showed that farming vertisols influenced their properties and increased their erodibility. Also, slope gradient increased vertisols erodibility. Statistical analyses revealed that nitrogen, amorphous $\mathrm{Al}$ and $\mathrm{K}^{+}$were the most dispersive elements while $\mathrm{OM}, \mathrm{Mg}^{++}$and amorphous $\mathrm{Fe}$ were the important elements which promote aggregates stability. For the well management of the studied soils which are annually cropped, no-tillage or minimum tillage (oriented perpendicularly to the slope) are practices to be implemented; nitrogen and potassium rich inputs notably NPK fertilizers and urea have to be controlled. Same attention has to be taken for liming practices. In contrast, substantial organic inputs through manures and compost, fertilizers and amendment susceptible to enhance soil content in $\mathrm{Mg}^{++}$and amorphous $\mathrm{Fe}$ have to be encouraged. Implementation of dams like earth bunds and micro catchments may also be benefic to efforts in minimizing soil erosion effect. The suggested practices must be tested before their vulgarization to farmers.

\section{Acknowledgements}

The authors thank the anonymous reviewers for valuable comments that improved the manuscript. They gratefully acknowledge farmers of the studied sites for providing information about farming practices.

\section{References}

Abbaslou, H., F. Martin, A. Abtahi and F. Moore. 2014. Traces elements concentrations and background values in the arid soils of Hormozgan province of southern Iran. Archives of Agronomy and Soil Science 60(8): 1125-1143.

Amezketa, E. 1999. Soil aggregate stability: A review. Journal of Sustainable Agriculture 14: 83-151.

Azinwi, P.T., E.W. Djoufac, D. Bitom and D. Njopwouo. 
2011. Petrological, physico-chemical and mechanical characterization of the topomorphic vertisols from the Sudano-sahelian region of North Cameroon. The Open Geology Journal 5: 33-55.

Bajracharya, R.M., W.J. Elliot and R. Lal. 1992. Interrill erodibility of some Ohio soils based on field rainfall simulation. Soil Science Society of America Journal 56: 267-272.

Basga, S.D., D. Tsozué, J.P. Temga, J. Balna and J.P. Nguetnkam. 2018. Land use impact on clay dispersion/flocculation in irrigated and flooded vertisols from Northern Cameroon. International Soil and Water Conservation Research 6(3): 237-244

Basga, S.D. and J.P. Nguetnkam. 2015. Fertilizing effect of swelling clay materials on the growth and yield of bean "Phaseolus vulgaris" on the sandy ferruginous soils from Mafa Tchéboa (North Cameroun, Central Africa). International Journal of Plant and Soil Science 5(1): 10-24.

Basic, F., I. Kisic, M. Mesic, O. Nestroy and A. Butorac. 2004. Tillage and crop management effects on soil erosion in Central Croatia. Soil \& Tillage Research 78: 197- 206.

Bechtold, J.S. 2007. Fluvial sediment influences on floodplain soil biochemistry. (Doctoral dissertation). Washington University, USA.

Brabant, P. 1968. Sols ferrugineux tropicaux et sols apparentés du Nord Cameroun : Aspects de leur pédogenèse. Rapport IRCAM, Yaoundé, 168:41p. (multigr).

Brabant, P. and M. Gavaud. 1985. Soils and land resources of North Cameroon (North and Far North Provinces). Paris, ORSTOM-MESRES-IRA.

Brubaker, S.C., C.S. Holzhey and B.R. Brasher. 1992. Estimating the water dispersive clay content of soils. Soil Science Society of America Journal 56: 267-272.

Chenu, Le Bissonnais and Arrouays. 2000. Organic matter influence on clay wettability and soil aggregate stability. Soil Science Society of America Journal 64: 1479-1486

Duiker, S.W., F.E Rhoton., J. Torrent, N.E. Smeck and R. Lal. 2003. Iron (hydr) oxide crystallinity effects on soil aggregation. Soil Science Society of America Journal 67: 606-611.

Essien, O.E. 2013. Evaluation of potential erodibility of basin wetland using soil particles distribution. IOSR Journal of Agriculture and Veterinary Science 4(4): 1016.

FAO. 2006. Guidelines for Soil Description. A Framework for International Classification, Correlation and Communication, $4^{\text {th }}$ Ed., FAO, Rome, Italy.
Fils, N.S.C., J. Etouna and M. Hakdaoui. 2014. Apport de l'OT et de SIG à la cartographie des zones à risque d'érosion hydrique dans le bassin versant productif de Sangueré, Nord-Cameroun, Afrique centrale. Inter. Journal of Innovation and Applied Studies 9: 448- 479.

Fontes, M.F., G.B. Gjorup, R.C. Alvarenga and P.G.S. Nascif. 1995. Calcium salts and mechanical stress effects on water dispersible clay of oxisols. Soil Science Society of America Journal 59: 224-227.

Fontes, J.C., L.S. Pereira and R.E. Smith. 2004. Runoff and erosion in volcanic soils of Azores: Simulation with OPUS. Catena 56: 199-212.

Gavaud, M., J.P. Muller and M. Fromaget. 1976. Les étapes des évolutions des sols dans les alluvions de la Bénoué (Nord Cameroun). Cah. ORSTOM, sér. pédol, 14: 321335.

Gisilanbe, S.A., H.J., Philip, R.I. Solomon and E.E. Okorie. 2017. Variation in soil physical and chemical properties as affected by three slope positions and their management implications in Ganye, North-Eastern Nigeria. Asian Journal of Soil Science and Plant Nutrition 2(3): 1-13.

Goldberg, S., B.S. Kapoor and J.D. Rhoades. 1990. Effect of aluminium and iron oxides and organic matter on flocculation and dispersion of arid zone soils. Soil Science 150: 588-593.

Gonzalez, J.M. 2018. Runoff and losses of nutrients and herbicides under long-term conservation practices (notill and crop rotation) in the U.S. Midwest : A variable intensity simulated rainfall approach. International Journal of Plant and Soil Science 6(1): 206-274.

Jamshidi, A.R., and A. Afrous. 2015. Impact of slope, tillage systems and methods of cultivation on the rate of soil erosion in cultivating rain fed wheat of Khozestan province. Journal of Scientific Research and Development 2 (2): 74-78.

L'Hote, Y. 2000. Climatologie. p.27-33. In : Atlas de la province de l'Extrême Nord-Cameroun. C. Seignobos and O. Iyebi-Mandjek (eds.). IRD. MINREST, Paris.

Humbel, F.X. and J. Barbery. 1973. Carte pédologique du Nord Cameroun. Feuille Garoua. ORSTOM.

Igwe, C.A., F.O.R. Akamigbo and J.S.C. Mbagwu. 1995. Physical properties of soils of southern Nigeria and the role of some aggregating agents in their stability. Soil Science 160: 431-441.

Igwe, C.A., 2005. Erodibility in relation to water dispersible clay for some soils of Eastern Nigeria. Land Degradation \& Development 16: 87-96.

Igwe, C.A. and O.N. Udegbunam. 2008. Soil properties influencing water-dispersible clay in an Ultisol in southern Nigeria. International Agrophysics 22: 319- 
325.

Igwe, C.A., M. Zarei and K. Stahr. 2009. Colloidal stability in some tropical soils of southeastern Nigeria as affected by iron and aluminium oxides. Catena 77: 232237.

Igwe C.A., M. Zarei and K. Stahr. 2013. Stability of aggregates of some weathered soils in south-eastern Nigeria in relation to their geochemical properties. Journal of Earth System Science 122 (5): 1283-1294.

Jackson, M.L. 1973. Soil Chemical Analysis. Prentice Hall of India Pvt. Ltd., New Delhi, 498p.

Koutika, L.S., F. Bartoli, F. Andreux, C.C. Cerri, G. Burtin, T. Chone and R. Philippy. 1997. Organic matters dynamics and aggregation in soils under rain forest and pastures of increasing age in the eastern Amazon Basin. Geoderma 76: 87-112.

Kovda, I.V. and L.P. Wilding. 2004. Vertisols: Problems of classification, evolution and spatial self-organization. Eurasian Soil Science 37: 1341-1351.

Lal, R. 1997. Soil degradative effects of slope length and tillage methods on alfisols in western Nigeria. III soil physical properties. Land Degradation and Development 8: 325-342.

Letouzey, R. 1985. Notice explicative de la carte phytogéographique du Cameroun au 1/500000. Domaine sahéliens et soudaniens $25 \mathrm{p}$.

Madejová, J. 2003. FTIR techniques in clay mineral studies. Vibrational Spectroscopy 31(1): 1-10.

Mainam, F., J.A. Zinck and E. Van Ranst. 2002. Modeling interrill soil erosion in the semiarid zone of Cameroon. 17th WCSS, 14- 21 August 2002, Thailand.

Martz, W.L. 1992. The variation of soil erodibility with slope position in a cultivated Canadian prairie landscape. Earth Surface Processes and Landforms 17: 543-556.

Nguetnkam, J.P. and S. Dultz. 2011. Soil degradation in Central North Cameroon: Water dispersable clay in relation to surface charge in oxisol A and B horizons. Soil \& Tillage Research 113: 38-47.

Nguetnkam, J.P. and S. Dultz. 2014. Clay dispersion in typical soils of north Cameroon as a function of $\mathrm{pH}$ and electrolyte concentration. Land Degradation \& Development 25: 153-162.

Oades, J.M., 1984. Soil organic matter and structure stability, mechanism and implication for measurement. Plant and Soil 76: 319-337.

Olivry, J.C, 1986. Fleuves et rivières du Cameroun. Collection « Monographies hydrologiques ORSTOM » $\mathrm{N}^{\circ}$ 9. Paris.

Park, S. 2002. Mapping soil organic matter content in floodplains using a digital soil database and GIS techniques: A case study with a topographic factor in northwest Kausas. The journal of GIS Association of Korea 10: 533-550.

Petit, S., D. Righi, J. Madejova, and A. Decarreau. 1998. Layer charge estimation of smectites infrared spectroscopy. Clay Minerals 33: 579- 591.

Pias, G. 1970. Les formations sédimentaires tertiaries et quaternaires de la cuvette tchadienne et les sols qui en dérivent. Mem. ORSTOM (43), 408p.

Pinheiro-Dick, D. and U. Schwertmann. 1996. Microaggregates from oxisols and inceptisols: dispersion through selective dissolutions and physicochemical treatments. Geoderma 74: 49-63.

Plaza-Bonilla, D., Cantero-Martınez and J. Alvaro-Fuentes. 2010. Tillage effects on soil aggregation and soil organic carbon profile distribution under Mediterranean semi-arid conditions. Soil Use and Management 26: 465-474.

Roose, E. 1994. Introduction à la gestion conservatoire de l'eau, de la biomasse et de la fertilité des sols. Bulletin de la FAO 70, $420 \mathrm{p}$.

Roose, E. and B. Barthes. 2001. Organic matter management for soil conservation and productivity restoration in Africa: A contribution from French speaking research. Nutrient Cycling in Agro Ecosystems 61: $159-170$.

Roose, E. and De Noni. 2004. Recherches sur l'érosion hydrique en Afrique : revue et perspectives. Sécheresse 15(1): 121-129.

Roth, C.H. and M.A. Pavan. 1991. Effects of lime and gypsum on clay dispersion and infiltration in samples of a Brazilian Oxisol. Geoderma 48: 351-361.

Rhoton F.E., Emmerich W.E., Goodrich D.C., Miller S.N., Mc Chesney D.S. 2007. An aggregation/erodibility index for soils in a semiarid watershed, Southeastern Arizona. Soil Science Society of America Journal 71(3): 984-992.

Salako, F.K. 2001. Structural stability of an alfisol under various fallow management practices in Southwestern Nigeria. Land Degradation \& Development 12: 319328.

Schwertmann, U. 1964. Differenzierung der Eisenoxide des Bodens durch Extraktion mit AmmoniumoxalatLösung. Z. Pflanzenernähr. Düng. Bodenkd 105(3): 194-202.

Seiny-Boukar L., C. Floret, K.H. Moukouri and R. Pontanier. 1991. Dégradation des vertisols dans le Nord-Cameroun : Modification du régime hydrique des terres et tentative de réhabilitation. p.287-294. In: AUPELF-UREF. John Libbey Eurotext (ed.). Paris.

Six, J., H. Bossuyt, S. De Gryze and K. Denef. 2004. A history of research on the link between (micro) aggregates, soil Biota and soil organic matter dynamics. 
Soil \& Tillage Research 79: 7-31.

Six, J., K. Paustian, E.T. Elliot and C. Combrink. 2000. Soil structure and organic matter: Distribution of aggregatesize classes and aggregate-associated carbon. Soil Science Society of America Journal 64: 681-689.

Tahernezami, M. 2013. Effect of land use types and slope on soil erodibility factor in Alborz province, Iran. International Research Journal of Applied and Basic Sciences 4: 25-30.

Tejada, M. and J.L. Gonzalez. 2006. The relationships between erodibility and erosion in a soil treated with two organic amendments. Soil \& Tillage Research 91: 186-198.

Temga, J.P., T.P. Azinwi; S.D. Basga, P. Zo'o Zame, H. Gouban; A.M. bessolo, J.P. Nguetnkam and D.L. Bitom. 2019. Characteristics, classification and genesis of vertisols under seasonally contrasted climate in the Lake Chad Basin, Central Africa. Journal of African Earth Sciences 150: 176-193.

Temga, J.P., J.P. Nguetnkam, M.A. Balo, S.D. Basga and D.L. Bitom. 2015. Morphological, physico chemical, mineralogical and geochemical properties of vertisols used in bricks production in the Logone Valley (Cameroon, Central Africa). International Journal of Geology and Mining 5(2): 20-30.
Tisdall, J.M. and J.M. Oades. 1982. Organic matter and water stable aggregates in soils. Journal of Soil Science 33: $141-163$.

Vizier, JF. 2010. Les phénomènes d'hydromorphie en régions tropicales à saisons contrastées - Application à une meilleure caractérisation des concepts de gley et de pseudogley. AFES, 225-238.

Wagner, S., S.R. Cattle and T. Scholten. 2007. Soil aggregate-formation as influenced by clay content and organic matter amendment. Journal of Plant Nutrition and Soil Science 170: 173-180.

Walkley, A. and I.A. Black. 1934. Determination of organic matter in soil. Soil Science 37: 549-556.

WRB, 2014. World Reference for soil Base resources. International soil classification system for naming soils and creating legends for soil maps. World Soil Resources Reports $\mathrm{N}^{\circ} 106$. FAO, Rome.

Wuddivira, M.N. and G. Camps-Roach. 2007. Effects of organic matter and calcium on soil structural stability. European journal of soil science 58: 722-727. 